\title{
Metafizyka w ekologii? Ekosystem jako Złożony System Adaptacyjny
}

\section{MAGDALENA CZARNECKA}

Pracownia Hydrobiologii Stosowanej, Wydział Biologii i Ochrony Środowiska, Uniwersytet Mikołaja Kopernika, Toruń mczarn@umk.pl

Streszczenie. Metafizyczne poszukiwania dotyczące pochodzenia i ewolucji życia są również obecne w ekologii, jednakże odnoszą się nie do pojedynczych organizmów, ale całych systemów ekologicznych, takich jak ekosystem czy biosfera. Ekosystem (biosfera) może być rozważany jako Złożony System Adaptacyjny, na który składają się liczne, różnorodne i autonomiczne jednostki, połączone gęstą siecią interakcji. Istotną cechą złożonych systemów jest zdolność do uczenia się oraz do samoorganizacji, która jest rezultatem adaptowania się do zmian w środowisku. Zrozumienie struktury i funkcjonowania ekosystemu oraz ścieżek jego ewolucji stanowi obecnie jedno z największych wyzwań współczesnej ekologii. W badaniach ekologicznych często dominuje podejście redukcjonistyczne, według którego wszystkie aspekty życia można wyjaśnić na poziomie procesów fizycznych i chemicznych bądź molekularnych. Jednakże badania prowadzone nad złożonymi systemami pokazały, że zasady opisujące te układy nie mogą zostać wyprowadzone $z$ reguł podstawowych, a ich zachowanie wymyka się podstawowym prawom fizyki i jest w rzeczywistości bardzo trudne do przewidzenia. Co więcej, pewne aspekty ekologii związane z dynamiką żywych układów są wręcz pogwałceniem wszystkich postulatów Newtona. Interakcje pomiędzy poszczególnymi komponentami złożonego systemu ekologicznego są asymetryczne, przypadkowe, niezdeterminowane i nieliniowe. Ewolucja ekosystemu może być wytłumaczona poprzez ekologię procesu, odzwierciedlającą naturalną tendencję złożonego układu do samoorganizacji. Nieprzewidywalność zachowania złożonych układów oraz niemożność ujęcia wszystkich kompleksowych procesów ekologicznych w ramy dynamiki newtonowskiej stworzyła nową przestrzeń 
W świecie, który do tej pory jawił się jako zamknięty, atomistyczny i zdeterminowany. Przestrzeń, w której spotkanie pomiędzy nauką a wiarą staje się coraz bardziej możliwe.

Słowa kluczowe: ewolucja; pochodzenie życia; prawa Newtona; dobór naturalny; indeterminizm; biosfera; różnorodność biologiczna; ekologia procesu.

\begin{abstract}
Metaphysics in ecology? Ecosystem as a Complex Adaptive System. The metaphysical exploration regarding the origin and evolution of life is also present in ecology, however, does not refer to individual organisms, but entire ecological systems, such as ecosystems and the biosphere. Ecosystem (the biosphere) can be considered as a Complex Adaptive System, consisted of numerous, diverse, and autonomous entities, connected by a dense network of interactions. The essential feature of complex systems is the ability to learn and to self-organization, which is a result of adaptation to changes in the environment. Understanding the ecosystem structure and functioning as well as pathways of its evolution is one of the greatest challenges of modern ecology. Ecological studies are often dominated by the reductionist approach, whereby all aspects of life can be explained by physical, chemical, or molecular processes. However, studies on complex systems has shown that the rules describing these systems can not be derived from the basic principles; their behavior defies the basic laws of physics, and in fact is very difficult to predict. Moreover, some aspects of ecology related to the dynamics of living systems violate all the postulates of Newton. Interactions between particular components of a complex ecological systems are asymmetrical, casual, indeterminate, and non-linear. The evolution of the ecosystem can be explained by process ecology that reflects the natural tendency to self-organization of the complex system. The unpredictability of the behavior of complex systems and the inability to provide all the complex ecological processes within the framework of Newtonian dynamics has created a new space in the world that has so far appeared as closed, atomistic and determined. The space in which the reunion between science and faith is becoming increasingly possible.
\end{abstract}

Keywords: evolution; origins of life; Newtonian laws; natural selection; indeterminism; biosphere; biodiversity; process ecology.

\title{
Wstęp
}

Pochodzenie i ewolucja życia to jedne z najbardziej żywo dyskutowanych kwestii, zarówno w środowiskach nauk przyrodniczych, jak i filozoficznych oraz teologicznych. W tych metafizycznych poszukiwaniach środowisko nauk ścisłych jest reprezentowane głównie przez fizyków, którzy próbują wyjaśnić, w jaki sposób powstał i rozwijał się Wszechświat, oraz przez biologów, zwłaszcza ewolucjonistów, szukających odpowiedzi na pytanie: jak w martwym Wszechświecie powstało życie oraz w jaki sposób ono ewoluowało. Od wieków 
rozważania na temat pochodzenia i ewolucji życia są źródłem nieustannego napięcia pomiędzy zwolennikami kreacjonizmu a tymi, którzy postrzegają przyrodę jako byt samoistny, powstały i funkcjonujący bez ingerencji wyższej siły - Stworzyciela. Naukowcy na temat pochodzenia życia wyrażają się najczęściej w sposób kategoryczny - Stworzyciel nie jest do tego potrzebny (Hawking i Mlodinow, 2005). Wraz z pojawieniem się teorii doboru naturalnego sformułowanej przez Darwina możliwe stało się wyjaśnienie ewolucji życia jako rezultatu naturalnego procesu, polegającego na stopniowej akumulacji spontanicznie powstających mutacji, bez konieczności odwoływania się do Inteligentnego Projektanta (Ayala, 2007), a istnienie fizycznych praw, takich jak grawitacja, stało się uzasadnieniem zdolności Wszechświata do „stworzenia siebie samego z niczego" (Hawking i Mlodinow, 2010).

Metafizyczne poszukiwania są również obecne w ekologii i można powiedzieć, że stanowią one syntezę podejścia reprezentowanego zarówno przez fizyków, jak i biologów. Ekologia bowiem jest kompleksową, interdyscyplinarną dziedziną, która według klasycznej definicji Ernsta Haeckla $(1869)^{1}$, zajmuje się badaniem powiązań pomiędzy organizmami żywymi a otaczającym je środowiskiem ożywionym i nieożywionym. Ogólniej rzecz ujmując, jest nauką o strukturze i funkcjonowaniu przyrody (Odum, 1963). Krebs (2011) wyróżnia kilka wzajemnie uzupełniających się dziedzin ekologii: ekologię opisową określaną jako „historię naturalną”, polegającą na opisywaniu całych formacji roślinnych kuli ziemskiej i zgrupowań zwierząt oraz ekologię funkcjonalną, która poszukuje i bada wzajemne zależności między składowymi jednostek analizowanych przez ekologię opisową oraz poszukuje ogólnych zasad funkcjonowania systemów ekologicznych. Zrozumienie reguł rządzących systemami ekologicznymi jest możliwe jedynie w kontekście teorii ewolucji, zatem ważną dziedziną jest także ekologia ewolucyjna, rozważająca organizmy i relacje istniejące między nimi jako twory historycznego procesu ewolucji. W centrum zainteresowania ekologii znajdują się zatem nie pojedyncze organizmy, ale raczej bardziej złożone struktury o różnym poziomie organizacji: począwszy od populacji, którą można zdefiniować jako

1 Krebs, Charles. Ekologia. Eksperymentalna analiza rozmieszczenia i liczebności. Warszawa: Wydawnictwo Naukowe PWN, 2011. 
grupę organizmów należących do tego samego gatunku, współwystępujących na określonym obszarze i w określonym czasie (Krebs, 2011), poprzez ekosystemy, czyli jednostki ekologiczne obejmujące wszystkie organizmy (populacje) na danym obszarze, współdziałające ze środowiskiem fizycznym (Odum, 1977), a skończywszy na najwyższym poziomie organizacji - biosferze, która obejmuje wszystkie globalne ekosystemy (Krebs, 2011).

Zrozumienie struktury, funkcjonowania oraz ścieżek ewolucji złożonych układów: ekosystemów i biosfery stanowi obecnie największe wyzwanie w ekologii, zważywszy zwłaszcza, że ta młoda dziedzina nauki nie posiada tak mocnej podstawy teoretycznej jak fizyka czy chemia. Dlatego też najczęściej dominuje tutaj podejście redukcjonistyczne, zgodnie z którym wszystkie aspekty życia można wyjaśnić na poziomie procesów fizycznych i chemicznych (Krebs, 2011), bądź genetycznych (Ayala, 2007). Niewątpliwie, zjawiska i procesy zachodzące w układach ekologicznych, osadzone w konkretnym środowisku fizycznym i realizujące nieustannie przemianę materii za pośrednictwem organizmów, są ograniczane prawami fizycznymi: zasadami dynamiki Newtona oraz prawami termodynamiki (Ulanowicz, 2007; Weiner, 2008). Natomiast centralny paradygmat w biologii, jakim jest Darwinowska teoria doboru naturalnego, nadaje sens biologicznym funkcjom organizmów oraz interakcjom zachodzącym pomiędzy nimi i w ten sposób przyczynia się do zrozumienia struktury i funkcjonowania układów ekologicznych (Longo i in., 2012).

Teoretycznie, znając podstawowe prawa fizyki, prawa cząstek i oddziaływań można wyjaśnić funkcjonowanie wszystkiego, co z nich złożone, również układów ekologicznych. Jednakże badania prowadzone nad złożonymi systemami pokazały, że zasady opisujące te układy nie mogą zostać łatwo wyprowadzone z reguł podstawowych, a ich zachowanie wymyka się podstawowym prawom fizyki i jest w rzeczywistości bardzo trudne do przewidzenia. Co więcej, pewne aspekty ekologii związane z dynamiką żywych układów są wręcz pogwałceniem wszystkich postulatów Newtona (Ulanowicz 2007; Ulanowicz, 2009), a my nie jesteśmy w stanie sformułować żadnego równania ruchu dla ewoluującej biosfery (Longo i in., 2012). Niespodziewanie, nieprzewidywalność zachowania złożonych układów oraz niemożność ujęcia wszyst- 
kich kompleksowych procesów ekologicznych w ramy dynamiki newtonowskiej stworzyła nową przestrzeń w świecie, który do tej pory jawił się jako zamknięty, atomistyczny i zdeterminowany. Przestrzeń, w której spotkanie pomiędzy nauką a wiarą staje się coraz bardziej możliwe (Ulanowicz, 2010).

\section{1. Świat według Newtona}

Ulanowicz (2007) przedstawił pięć aksjomatów dotyczących podejścia do zjawisk naturalnych, będących dziedzictwem fizyki newtonowskiej:

(1) Systemy newtonowskie są przyczynowo zamknięte, co znaczy, że jedynie mechaniczne lub materialne przyczyny są zasadne i zawsze ze sobą współwystępują.

(2) Systemy newtonowskie są atomistyczne. Są możliwe do rozłożenia na mniejsze, stabilne jednostki, które mogą być ponownie złożone.

(3) Systemy newtonowskie są odwracalne. Prawa rządzące zachowaniem systemu działają w obu czasowych kierunkach. Jest to konsekwencja symetrii czasu obecnej we wszystkich prawach Newtona.

(4) Systemy newtonowskie są zdeterminowane. Przy precyzyjnie podanych warunkach początkowych, przyszłe (lub przeszłe) stany systemu mogą zostać przewidziane.

(5) Fizyczne prawa są uniwersalne. Mogą zostać zastosowane wszędzie, w każdym czasie i w każdej skali.

Zgodnie z powyższym, przyroda może być postrzegana jako zbiór martwej materii, poruszającej się zgodnie z deterministycznymi, konserwatywnymi prawami, których prosta natura nie pozostawia miejsca na asymetrię i przypadek, które często rządzą żywymi systemami (Ulanowicz, 2010).

\section{Złożone Systemy Adaptacyjne - ich struktura i funkcjonowanie}

Zarówno ekosystemy, jak i biosfera to niezwykle złożone układy, a ściślej rzecz ujmując, specjalne przypadki, które można określić jako Złożone Systemy Adaptacyjne (Complex Adaptive Systems, CAS). CAS tworzą pewną całość, złożoną z licznych, różnorodnych i autonomicznych jednostek, zwa- 
nych agentami, połączonych gęstą siecią zależności. Ich cechą, jako całości, jest zdolność do uczenia się na podstawie doświadczenia oraz zdolność do samoorganizacji, która jest wyrazem adaptowania się do zmian w środowisku, a nie tylko reagowania na nie. Ponadto wszystkie złożone systemy posiadają swoją własną historię, ewoluują, a ich przeszłość jest współodpowiedzialna za ich obecne zachowanie. CAS działają w warunkach dalekich od termodynamicznej równowagi, zatem musi być utrzymany stały przepływ energii, żeby organizacja systemu mogła zostać utrzymana (Holland, 2006; Mitleton-Kelly, 2012). To ostatnie jest możliwe dzięki organizmom wchodzącym w skład systemu, przez które stale przepływa energia i następuje ciągła wymiana materii polegająca na ustawicznym przerabianiu zasobów pobranych z otoczenia. Co więcej, organizmy wykazują zdolność do samoregulacji i samoreplikacji. Niewielkie błędy zdarzające się przy wytwarzaniu kolejnych osobników są źródłem ich zmienności, co powoduje, że mogą różnić się one szansą przetrwania i wydania potomstwa w danych warunkach środowiskowych. W rezultacie, z pokolenia na pokolenie zmieniają się cechy strukturalne i funkcjonalne organizmów - powstają nowe formy, a przemiany te nazywane są ewolucją w drodze doboru naturalnego (Weiner, 2008).

Holland (1995) podaje cztery podstawowe własności każdego CAS, którymi są: agregacja, nieliniowość, różnorodność i przepływ. Własności te w trafny sposób opisują podstawowe właściwości ekosystemu jako układu złożonego.

Agregacja odnosi się do sposobu, w jaki poszczególne osobniki łączą się $\mathrm{w}$ populacje, populacje w gatunki, a gatunki w grupy funkcjonalne, spełniające podobne zadania w ekosystemie, np. odżywiające się w podobny sposób, podobnym pokarmem. Kształtowanie się wzorców agregacji i organizacji hierarchicznej są naturalną konsekwencją samoorganizacji każdego złożonego systemu, wynikają z przynależności taksonomicznej organizmów, warunków środowiskowych oraz lokalnych interakcji, a także mają wpływ na dalszy rozwój systemu (Levin, 1998).

W związku z tym, że CAS zmieniają się w wyniku wzmocnienia przypadkowych zdarzeń, takich jak mutacje czy zmienność warunków środowiska działających na poziomie lokalnym, liczba potencjalnych, alterna- 
tywnych ścieżek rozwoju systemu jest ogromna (Levin, 1998). Wynika to $\mathrm{z}$ faktu, że interakcje pomiędzy poszczególnymi komponentami systemu są nieliniowe, co znaczy, że niewielkie zmiany w systemie mogą pociągać za sobą ogromne skutki (Mitleton-Kelly, 2012). Ponadto ścieżki rozwoju CAS są uzależnione od historii układu, co także jest konsekwencją nieliniowości, a lokalnie działające zasady interakcji pomiędzy składnikami złożonego układu zmieniają się w miarę jego ewolucji (Levin, 1998). Takie nieliniowe interakcje są szczególnie widoczne w procesie sukcesji, czyli kierunkowego rozwoju biocenozy (zespołów populacji w ekosystemie), polegającej na kolonizacji nowego obszaru przez organizmy i na progresywnych zmianach flory i fauny, objawiających się jako następowanie po sobie różnych gatunków (Krebs, 2011). Nawet w prostych układach, takich jak przybrzeżne skały w środowisku morskim, zdominowanych przez dwa - trzy gatunki, choć widoczne są ogólne, powtarzalne wzorce sukcesji, ostateczny rezultat rozwoju biocenozy może być różny, nawet w obrębie porównywalnych pod względem warunków środowiska, blisko sąsiadujących ze sobą obszarów (Farrell, 1991). Wynika to nie tylko z czasu sukcesji, ale także licznych, trudnych do przewidzenia zdarzeń losowych, związanych z tempem rozprzestrzeniania się organizmów i kolonizacją nowych siedlisk (Farrell, 1991; Krebs, 2011).

Kluczową właściwością każdego złożonego systemu jest różnorodność poszczególnych elementów tego układu. W przypadku ekosystemów, w pewnym uproszczeniu, odnosi się to do liczby gatunków zasiedlających dany obszar (Levin, 1998), jak również do liczby potencjalnych nisz ekologicznych, wpływających na fizyczną złożoność ekosystemów, czyli miejsc w środowisku, które pozwalają na korzystanie z zasobów oraz skuteczne rozmnażanie się poszczególnych gatunków (Adami, 2002). Organizmy wchodzące w skład ekosystemu, należące do różnych gatunków, przyczyniają się do różnorodności gatunkowej i genetycznej, podtrzymującej strukturę i funkcjonowanie systemu (Levin, 1998). Wysoce złożony ekosystem jest charakteryzowany przez znaczącą różnorodność, zarówno gatunków, jak i liczby potencjalnych połączeń i interakcji między nimi. Im większa różnorodność biologiczna w obrębie ekosystemu, tym większa jest jego stabilność i odporność na zakłócenia (Constanza i Mageau, 1999). Jednakże nie wszystkie gatunki są 
tak samo istotne dla utrzymania funkcji ekosystemu. Według koncepcji Paine`a (1966), najważniejsze są tzw. gatunki kluczowe (keystone species), które odgrywają nieproporcjonalnie dużą rolę w funkcjonowaniu ekosystemu, w porównaniu do ich liczebności. Usunięcie kluczowych gatunków z ekosystemu może wywołać nieliniowe skutki prowadzące do kaskadowego zanikania innych gatunków i fundamentalnych zmian w ekosystemie. Natomiast ogólniej rzecz ujmując, krytyczne dla ekosystemu procesy będą zależały nie od gatunków kluczowych, ale całych zestawów gatunków, które można określić jako kluczowe grupy funkcjonalne (keystone functional group) (Levin, 1998). Przykładem takich grup funkcjonalnych mogą być grzyby, które są odpowiedzialne za rozkład złożonych związków, takich jak celuloza czy ligniny i włączanie węgla do obiegu (Wong et al., 1998), czy też grupy mikroorganizmów odpowiedzialnych za wiązanie azotu (Levin, 1998). Procesy kontrolowane przez kluczowe grupy funkcjonalne będą miały dużo większe znaczenie dla istnienia ekosystemu niż procesy kontrolowane przez kluczowe gatunki. Różnorodność w obrębie grup funkcjonalnych będzie miała przed wszystkim znaczenie buforowe, podtrzymujące równowagę dla podstawowych procesów ekosystemu, podczas gdy różnorodność gatunkowa będzie sprzyjała odporności ekosystemu na potencjalne zakłócenia oraz będzie zabezpieczać gatunki przed wymieraniem (Levin, 1998).

Kolejny atrybut złożonego układu, jakim jest ekosystem, stanowi przepływ energii, związków biogennych, materii i informacji. Przepływ ten stwarza połączenia pomiędzy poszczególnymi częściami systemu: zarówno organizmami, jak i jego nieożywionymi elementami, i przyczynia się do transformacji zbiorowiska organizmów z przypadkowej grupy gatunków do zintegrowanej całości, w którym elementy ożywione i nieożywione stanowią powiązane ze sobą części (Levin, 1998). Przykładem takich połączeń w ekosystemie, bodaj najłatwiejszych do uchwycenia, są sieci troficzne, które obrazują powiązania pokarmowe pomiędzy organizmami i szlaki metaboliczne odzwierciedlające stopniową dekompozycję biomasy, która została wyprodukowana przez producentów. Relacje pomiędzy poszczególnymi komponentami sieci troficznej są wyznaczane właśnie przez przepływ energii i materii (Weiner, 2008). 


\section{Emergencja}

Mnogość poszczególnych składników wchodzących w skład złożonego systemu oraz ogromna liczba potencjalnych powiązań i interakcji zachodzących pomiędzy tymi komponentami sprawia, że CAS to coś więcej niż tylko suma stanowiących ją części. Zachowanie i właściwości całego systemu nie mogą być przewidziane na podstawie zachowania i właściwości tworzących go komponentów (Holland, 1995), co czyni złożony układ emergentnym. Poszczególne elementy: komórki i organizmy w złożonym systemie mogą być rozważane jako Kantowska całość, gdzie całość jest produktem poszczególnych jej części, a funkcjonowanie i istnienie części zależy od całości (Guyer, 2004; Longo i in., 2012). Mimo to, przykładowo na podstawie znajomości budowy molekularnej pojedynczych organizmów, chociaż geny w dużym stopniu determinują ich funkcje i zachowanie, nie jesteśmy w stanie ani wytłumaczyć zachowania złożonych z nich układów przyrodniczych, ani też zrozumieć, w jaki sposób te systemy powstawały i ewoluowały². Ponadto CAS zasadniczo różnią się od sztywnych, mechanistycznych systemów, gdyż zmieniają się w odpowiedzi na bodźce otrzymane ze środowiska, aby przetrwać w obliczu zmieniających się warunków (Mitleton-Kelly, 2012), a konsekwencje ich adaptacji są trudne do przewidzenia, ponieważ są efektem nakładających się na siebie losowych zdarzeń (Ulanowicz, 2007). Konwencjonalna teoria prawdopodobieństwa zakłada, że zdarzenia przypadkowe są proste, powszechne i powtarzalne (Ulanowicz, 2009), jednakże jak podaje Ulanowicz (1999) za fizykiem Walterem Elsasserem, przeważająca większość stochastycznych zdarzeń w biologii jest unikalna i nigdy się nie powtarza. Różnorodność i ogromna liczba potencjalnych kombinacji, które mogłyby pojawić się w obrębie żywych systemów sprawia, że mogą one przynieść rezultaty, których w żaden sposób nie można zdeterminować (Ulanowicz, 2007). Unikalne, pojedyncze zdarzenia występują cały czas, wszędzie, w każdej skali. Zatem, czy możliwe kombinacje czterech praw

2 Drugie odkrycie świętości. Rozmowa Karola Jałochowskiego ze Stuartem Kauffmanem, pionierem bioinformatyki, filozofem, wizjonerem nauki badającym ewolucję życia, kultury i technologii o związkach między życiem, fizyką, matematyką i Bogiem. Polityka, 21 czerwca 2011. 
Newtona i dwóch praw termodynamiki są w stanie objąć wszystkie potencjalne zmiany, które zachodzą w obrębie ekosystemu złożonego z tysięcy odrębnych organizmów? Zdaniem Ulanowicza (2010), prawa fizyki ograniczają zjawiska zachodzące w obrębie złożonych systemów biologicznych, jednakże są niewystarczające, by zdeterminować ich wynik. Co zatem definiuje ostateczny rezultat? Odpowiedzią może być proces.

\section{Ekologia procesu i ewolucja systemów złożonych}

Proces, według Ulanowicza (2009), może być zdefiniowany jako interakcja przypadkowych zdarzeń w stosunku do konfiguracji czynników ograniczających, które skutkują nie przypadkowym i jednocześnie nie zdeterminowanym wynikiem. Zgodnie z Ulanowiczem (2010), zanim pojawiła się materia, proces był już obecny. Na pytanie: jak to możliwe, że życie wyłoniło się z martwej materii, ekologia procesu odpowiada: nie istnieje materia, która jako taka początkuje życie. Raczej polega to na tym samym procesie ewolucji, który zapoczątkował zarówno materię, jak i życie. W podobny sposób argumentował Odum (1971), jeden z twórców współczesnej ekologii, formułując ekologiczny scenariusz początków życia. Według niego, proto-ekologiczne systemy musiały istnieć zanim jeszcze proto-organizmy mogły powstać. Taki proto-ekosystem, lub też konfiguracja cyklicznych procesów, mogły wywrzeć wpływ na ich poszczególne składniki i całkiem naturalnie doprowadzić do powstania bardziej skomplikowanych, ale mniejszych, cyklicznych konfiguracji, czyli proto-organizmów. Stuart Kauffman również definiuje życie jako wynik spontanicznej, niepohamowanej skłonności złożonych układów do samoorganizacji, przy czym Darwinowski dobór naturalny to proces wobec niej równoległy. Przypomina to koncepcję Alfreda Whiteheada dotyczącą „aktualnych bytów” (pierwotnych elementów organicznej rzeczywistości) i procesu stawania się Wszechświata ${ }^{3}$. Cała istota aktualnych bytów sprowadza się do tego, że wchodzą one w relację z innymi aktualnymi bytami. Aktualne byty nie są stałe, są odzwierciedleniem pro-

3 Heller, Michał. Filozofia przyrody. Kraków: Wydawnictwo Znak, 2007. 
cesu przemijania. Gdy w procesie wchodzenia w relację z innymi bytami, zwaną ujmowaniem, aktualne byty osiągną dojrzałość, zostają wchłonięte przez następne aktualne byty, które noszą w sobie ślady - za pośrednictwem ujmowania - dawnego bytu aktualnego. W ten sposób dzieje się proces Wszechświata, który jest nieustannym stawaniem się.

Longo i in. (2012) zwracają uwagę, że w kontekście analizy ewolucji organizmów, wyłania się głęboki aspekt wolności, wynikający z tego, że potencjalne „użycie” danej części lub procesu dotyczącego organizmu jest jednocześnie niesprecyzowane i nieuporządkowane, zatem nie można sporządzić żadnej efektywnej procedury czy algorytmu, która je zdefiniuje. Nowe części i procesy, jak adaptacje do warunków zewnętrznych oraz Darwinowskie preadaptacje, które polegają na tym, że cecha organizmu pierwotnie nieprzynosząca korzyści ewolucyjnej w danym środowisku może nabrać wartości w innym, powstają cały czas, najczęściej w wyniku licznych, nieokreślonych, przypadkowych i niepowiązanych ze sobą przyczynowo mutacji. W dodatku nowa funkcja organizmu jest wykorzystywana w nieprzewidywalnym środowisku, co także ma wpływ na kierunek ewolucji. W związku z tym, że nie jesteśmy w stanie przewidzieć ciągle zmieniających się obiektów i zmiennych ujawnianych w czasie doboru, nie możemy sformułować żadnego równania ruchu dla ewoluującej biosfery. Zatem, żadne prawo nie pociąga za sobą ewolucji biosfery, ani ściślej rzecz ujmując, filogenetycznej trajektorii organizmu.

\section{Zakończenie}

Złożona natura układów ekologicznych wymyka się mechanistycznym poglądom na funkcjonowanie przyrody: nie są one bowiem przyczynowo zamknięte, zdeterminowane i symetryczne (Ulanowicz, 2007). Zasady symetrii i matematyczne stałe nie mogą być w prosty sposób przeniesione na tworzenie teoretycznych ram w biologii, zwłaszcza jeśli chodzi o ewolucję żywych systemów (Longo i in., 2012). Nieprzewidywalność zachowania złożonych układów oraz nieliniowość procesów ekologicznych stwarza zatem nową perspektywę i przestrzeń dla wolności w świecie, który do tej 
pory jawił się jako zamknięty, atomistyczny i zdeterminowany. Zdaniem Ulanowicza (2010), skoro ekologia procesu pozwoliła przenieść dyskusję na temat początków życia z martwego świata molekuł na inny poziom, nie powinno dziwić, że może również zmniejszyć rzekomy konflikt pomiędzy nauką a religią, który wyrósł na gruncie fizyki Newtonowskiej. W kontekście emergencji, która jest naturalnym, zasadnym rezultatem procesów ekologicznych, wolna wola niekoniecznie musi być nadal zagadką. Istnienie stochastycznych zdarzeń rządzących przyrodą i układami żywymi, które nie są ani „ślepe” ani bezkierunkowe, nie są jeszcze dowodem Boskiej interwencji, ale sprawiają, że nie można jej już w sposób kategoryczny wykluczyć. Jako puenta niech posłużą słowa Jana Pawła II skierowane do o. Georga Coyne`a z okazji 300-lecia opublikowania Principiów Issaca Newtona ${ }^{4}$ : „Przy całym otwarciu pomiędzy Kościołem a wspólnotą naukową nie należy spodziewać się, że między teologią i nauką powstanie dyscyplinarna jedność podobna do tej, jaka istnieje w obrębie danej dziedziny naukowej czy też w obrębie samej teologii. W miarę jednak kontynuowania dialogu i wspólnych poszukiwań będzie następował postęp w kierunku wzajemnego zrozumienia oraz stopniowe odkrywanie wspólnych zainteresowań, które z kolei mogą stworzyć podstawy dla dalszych badań i dyskusji”.

\section{Bibliografia}

Adami, Christoph. 2002. “What is complexity?” BioEssays 24: 1085-94. DOI: http:// dx.doi.org/10.1002/bies.10192

Ayala, Francisco. 2007. "Darwin's greatest discovery: Design without designer.” PNAS 104: 8567-73.

Constanza, Robert, i Michael, Mageau. 1999. “What is a healthy ecosystem?” Aquatic Ecology 33: 105-15.

Guyer, Paul. 2004. “Kant, Immanuel.” W Routledge Encyclopedia of Philosophy. Ed. E. Craig. London: Routledge, 2004.

4 Heller, Michał. Bóg i nauka. Moje dwie drogi do jednego celu. Kraków: Copernicus Center Press, 2013. 
Farrell, Terence. 1991. "Models and mechanisms of succession: an example from a rocky intertidal community.” Ecological Monographs 61: 95-113. DOI: http:// dx.doi.org/10.2307/1943001

Hawking, Stephen, and Leonard Mlodinow. 2005. A briefer history of time. Bantam Books.

-. 2010. The grand design. Bantam Books.

Holland, John. 1995. Hidden order: how adaptation builds complexity. Addison Wesley.

-. 2006. "Studying Complex Adaptive Systems." Journal of Systems Science and Complexity 19: 1-8. DOI: http://dx.doi.org/10.1007/s11424-006-0001-z

Krebs, Charles. 2011. Ekologia. Eksperymentalna analiza rozmieszczenia i liczebności. Warszawa: Wydawnictwo Naukowe PWN.

Levin, Simon. 1998. "Ecosystems and the biosphere as Complex Adaptive Systems.” Ecosystems 1: 431-36. http://dx.doi.org/10.1007/s100219900037

Longo, Giuseppe, Maël Montévil, i Stuart Kauffmann. 2012. "No entailing laws, but enablement in the evolution of the biosphere." Complexity Digest 2: 1-19.

Mitleton-Kelly, Eve. 2003. "Ten principles of complexity and enabling infrastructures." W Complex systems and evolutionary perspectives on organisation: the application of complexity theory to organisations, 1-31. Oxford: Elsevier.

Odum, Eugene. 1963. Ecology. New York: Holt, Rinehart and Winston.

-. 1977. Podstawy ekologii. Warszawa: PWRiL.

Odum, Howard. 1971. Environment, power and society. New York: John Wiley and Sons.

Paine, Robert. 1966. "Food web complexity and species diversity.” American Naturalist 100: 65-75. DOI: http://dx.doi.org/10.1086/282400

Ulanowicz, Robert. 1999. “A life after Newton: An ecological metaphysic.” BioSystems 50: 127-42.

-. 2007. "Emergence, naturally!" Zygon: Journal of Religion and Science 42: 945-60.

-. 2009. A third window: natural life beyond Newton and Darwin. West Conshohocken: Templeton Foundation Press.

-. 2010. “From pessimism to hope: a natural progression.” Zygon: Journal of Religion and Science 45: 939-56.

Weiner, January. 2008. Życie i ewolucja biosfery. Warszawa: Wydawnictwo PWN.

Wong, Michelle, Teik-Khiang Goh, John Hodgkiss, Kevin Hyde, Mala Ranghoo, Clement Tsui, Wai-Hong Ho, Wilson Wong, i Tsz-Kit Yuen. 1998. "Role of fungi in freshwater ecosystems.” Biodiversity Conservation 7: 1187-206. 